\title{
THE IMPACT OF EMPLOYMENT EQUITY REGULATIONS ON PSYCHOLOGICAL CONTRACTS IN SOUTH AFRICA
}

\author{
Albert Wöcke \\ Senior Lecturer \\ Gordon Institute of Business Science \\ University of Pretoria \\ wockea@gibs.co.za \\ And \\ Margaret Sutherland \\ Associate Professor \\ Gordon Institute of Business Science \\ University of Pretoria \\ sutherlandm@gibs.co.za
}




\section{Key words: employment equity, psychological contract, South Africa, diversity management}

This paper will show the impact of employment equity legislation on the psychological employment contracts of the three main employee groupings in South African society. This study is important in that it fills the gap in the literature to identify labour market regulations as an important shaping influence on the psychological contract. More than 500 managers from across South African industry and from all ethnic groups were surveyed to identify differences in psychological contracts and attitudes towards the social transformation regulations. We found that the legislation has impacted differentially on the three groupings mainly in terms of their loyalty to stay with their

organisations, their focusing on their career development in terms of the external labour market and the degree to which they felt they had been impacted by the legislation. Additionally we find that the perceived linkage between job satisfaction and labour turnover is significantly weakened by labour market legislation in the case of the beneficiaries of the legislation, but may not be the case for those negatively affected by the legislation. The findings have significant implications for HR management practices of multinationals operating in societies with significant labour market regulatory interventions. 
There is little research on the influence of external regulations on the psychological contract in the developing world, yet these societies are generally in a high state of transition. South Africa is no exception. Since democracy in 1994, the South African government has introduced a plethora of legislation and regulation aimed at transformation to enable previously disadvantaged South Africans full access to all aspects of the economy including company ownership, share capital and top management positions. The impact of these interventions in terms of their impact on relations between employer and employee has not yet been subjected to a study of sufficient scale to understand the implications in detail. This study sampled a large cross section of South African managers using the validated Psychological Contract Inventory questionnaire (Rousseau, 2000). We build on a study by Maharaj (2003) which was done in a single

organisation. Respondents for our study were from a wide variety of South African companies, which deals with the problems of an in-company survey, such as the impact of organisational culture, leadership and an in-company HR strategy, all of which may be confounding variables in a study on the impact on psychological contracts.

\section{Psychological Contracts}

The concept of the psychological contract has become an important focus area for management researchers and practitioners in recent years because of the dominant resource based view of firm. The central premise is that employees are key to sustainable competitive advantage and it follows that relationships between employers and employees are critical to ensuring productivity and the continued release of innovation and creativity (Flood, Turner, Ramamoorthy \& Pearson, 2001). Psychological contracts 
are defined as promises expressed, or implied, that deal with exchange agreements between an employer and employee (Rousseau, 2004). Armstrong and Murlis (1998:22) define the psychological contract as the set of "expectations held by the individual employee that specify what the individual and the organisation expect to give and receive from one another in the course of their working relationship”.

Psychological contracts are also defined as distinctly denoting a relationship of exchange (Millward \& Brewerton, 2001) and having as their essence, reciprocity (Cappelli, 1997). There is an (often incorrect) belief in the mutality of the contract, they change and evolve over time, and there are several contract makers present in the company who include immediate supervisors, co-workers and HR departments (Rousseau, 2004). Rousseau (1995) states that the psychological contract can be influenced by external and internal factors. Maharj (2003) hypothesised that employment equity legislation in South Africa has the potential to challenge the mental models existing in psychological contracts.

Psychological contracts as viewed by employees can be transactional, transitional, relational, or balanced (Rousseau, 2000; Thompson \& Bunderson, 2003; Rousseau, 2004). Transactional contracts are of a short term duration primarily focused upon economic exchange with clearly specified roles and responsibilities. Relational contracts are about the exchange of socio-emotional currency in exchange for the organisation providing continued training and development, as well as long-term job security. This type of contract is seen as the more valuable for firms dependent on employees for their future sustainability as they are encouraged to contribute their commitment and loyalty to 
the organisation in exchange for their professional development (Rousseau \& McLean Parks, 1993; Flood et al, 2001, Thompson \& Bunderson, 2003). Balanced psychological contracts are open-ended arrangements with both parties contributing to each others learning and development, conditioned on the economic success of the employer. Transitional contracts refer to a "state of mind" reflecting the consequences of organisational change and transition that is at odds with a previously established employment arrangement i.e. a disruption to the psychological contract, and is evidenced in mistrust, uncertainty and an erosion of expectations.

\section{Outcomes of the psychological contract}

Effective management of psychological contracts relates to the maintenance of perceived obligations. A met psychological contract will lead to the knowledge worker feeling an obligation to contribute, and in the context of the modern workplace. This includes such behaviours as being a team player, expending extra effort as needed, and generally putting the organisation's interests before one's own. Flood et al (2001) found that the level of met expectations in a psychological contract have a direct effect on the employee’s commitment to the organisation and their intention to stay.

The violation of psychological contracts is known to have material effects on the relationship between the employer and employee (Robinson \& Morrison, 2000). As the relationship is based on the principle of reciprocity, when an employee experiences a breach of the psychological contract, employees may withhold their contributions to the organisation, and in some instances leave the organisation (Restubog, Bordia \& Tang, 
2006). A violation of the psychological contract leads to a variety of reactions, dependent on the severity of the breach and the nature of the psychological contract. According to Rousseau (2004), Coyle-Shapiro and Kessler (2000) and Rousseau \& McLean Parks (1993) breaches of transactional psychological contracts lead to an exit from the organisation, while breaches of relational psychological contracts can lead to a variety of reactions ranging from the withdrawal of commitment, reverting to economic (or transactional) contract, turnover, or further actions to diminish the employment relationship. It can be expected then that a perceived breach of the psychological contract by both white males and designated employees will lead to a withdrawal of commitment or exit from the organisation or a devaluation of the relational contract to a transactional one in the South African context.

\section{Intention to leave and labour turnover}

Bussin (2002) reports that the issue of increasing retention and decreasing turnover has become paramount in organisational life, and that attracting and retaining key talent has become a critical organisational competency. One of the key features of knowledge workers in the new world of work is their increasing mobility and the consequences of this to the organisation. The mobility of these knowledge workers is a major concern in the new economy as their departure from an organisation means loss of both tangible and intangible knowledge and possibly competitive advantage (Kinnear \& Sutherland, 2000). Templer and Cawsey (1999) regard knowledge workers as having portfolio careers, meaning that they have a portfolio of skills that they sell to a range of clients. 
The work of Morrell et al. (2001) identifies two schools of turnover research and subsequent modelling. They firstly describe the labour market school or economic school, which looks at issues such as labour supply and demand, job search theory and techniques, and objective opportunities impacts on labour turnover. The state of the labour market is deemed to be a determinant of attrition although the evidence is often contradictory. Milkovich and Boudreau (1997) explain that unemployment rates, informational access to job availability and visibility of other organisations. Yet, Lee et al. (1999) find that the literature shows an inconsistent relationship between the perceived number and type of job alternatives and turnover. Maertz and Campion (2001) in their statistical analysis find constant positive, but small, correlations between turnover and perceived alternative opportunities.

The other school of research, they term the "psychological school", where issues of affect are studied; emphasis is placed on individual decision making and, in particular, on the impact of job dissatisfaction and organisational commitment as antecedents of turnover. Gaertner (1999) comments that, most turnover models view organisational commitment and job satisfaction as intervening variables in the turnover process. Noe, Hollenbeck, Gerhart and Wright (2000) also found job dissatisfaction an antecedent to withdrawal in their study. However, in contrast, the Corporate Leadership Council (1999) found in their study that two thirds of the knowledge workers surveyed who intend to leave their employer within a year are satisfied with their current job. 
Van Scotter (2000) finds that turnover can best be described as the culmination of a series of withdrawal behaviours. Milkovich and Boudreau (1997) write that employees have withdrawal cognitions which lead to comparisons between the utility of leaving or staying. Winterton (2004) found that where labour market opportunities and ease of movement are high, then even someone with high job satisfaction would leave an organisation. Pearson (1991) identifies two groups in the mobile labour market. The first of these are the opportunists, who are marked by their confidence and adaptability, are successful, and make full use of their skills, and make unplanned employer changes when offered a better deal. The other group Pearson (1991) identifies as the seekers who are dissatisfied in some way with their current job and would like to make a career move.

Intention to leave is seen by many writers as the best predictor of turnover. The Corporate Leadership Council (1999), showed a strong correlation between intention to depart and actual turnover. Similarly, Lee et al. (1999), state that intention to leave is the immediate antecedent of departure and the highest predictor of departure. Likewise, Maertz and Campion (2001) in their large scale analysis of turnover research find that intention to leave has demonstrated the most consistent bi-variate relationship to turnover behaviour with an $r$ value consistently around the 0.50 level.

\section{Employment Equity Regulations In South Africa}

According to Booysen (2005:9) "On the journey towards transformation a number of Law Reform efforts and Employment Equity legislation have been initiated in South Africa to achieve social justice and equality and to redress past unfair discrimination”. 
The transformation of South Africa's workplace is driven by the need to dismantle the legacy of apartheid by transforming the basic structure, culture and core values of South African society to ensure equitable access to resources, opportunities and skills (Esterhuyse, 2003; Selby, 2005). This transformation led to the introduction of a variety of Employment Equity legislation, the most important of which are the Constitution of South Africa (1996) and the Employment Equity Act (1998), which seeks to promote equal opportunity in the workplace by requiring actions in the workplace, with affirmative action occupying a central role. The Act requires employers implement various forms of preferential treatment to designated groups to redress historical discrepancies in the distribution of jobs, occupations and incomes and ensure an equitable distribution of all groups in all occupations and levels in the workplace. The Employment Equity Act (1998) distinguishes between white males and previously disadvantaged individuals (PDI's) from the designated groups. Designated groups include Africans, Coloured (mixed race) and Indians, white females and the physically disadvantaged. This Act is supported by the Skills Development Act (1998) and the Skills Levies Act (1999), which shift the focus from only employment equity appointments to the recruitment, development and training of individuals from the designated groups. These Acts were followed by the Broad-Based Black Economic Empowerment Commission in 1999 which set out policies and strategies for the acceleration of the transformation process (Booysen, 2005). This was followed by the Black Economic Empowerment Act (2003) and Black Economic Empowerment Charters for several industries in which quotas for black management and black ownership where agreed. Disparities emerged from the various acts and charters and government 
intervened further with the introduction of a Draft Code of Practice for industries to set up their Black Economic Empowerment schemes (Bouche and Booysen, 2005; Booysen, 2005).

\section{Labour Market Influences}

Apartheid legislation disrupted the labour market and advantaged the minority of the population, the White group (Thomas and Jain, 2004). The post 1994 legislation has had as its central mission to disrupt the labour market once again, this time to empower the majority of the population (Thomas and Jain, 2004), the Black Africans, in order to redress the past injustices. The measures are aimed at ensuring that the designated groups have equitable representation depending on their availability in the external labour market; however the very history of the country has ensured a shortage of highly skilled Black employees due to the previous lack of education, training and development opportunities. One of the principles of the perfectively competitive labour market is where workers have identical comparable skills. Labour market regulation is the opposite of perfect competition (Reddy, 2004). The legislation has thus caused an imperfection, or disruption in the labour market. The current labour legislation can be seen as sheltering equity candidates and posing a barrier to others (Reddy, 2004). Consequently the legislation has artificially increased the demand for skilled black employees. Reddy also states that increasing market flexibility has led to the corrosion of the psychological contract between employer and employee, resulting in the employees taking their careers into their own hands, thereby reducing their loyalty to the organisation. 


\section{The Three Social Identities in the Workplace}

These interventions have led to significant changes in the workplace and Ngambi (2002) and Booysen (2004a and 2004b) identify several examples of intergroup anxiety and tension that have resulted from the apartheid legacy and transformation efforts. Booysen (2004b and 2005) maintains that there are three social identities present in the South African workplace: white males, Africans and a "middle group" consisting of white females, coloureds and Indians. This overlaps somewhat with the designated groups as defined in the legislation (which also includes all Africans) Social identities emerge when individuals tend to identify themselves and others into social categories and these have significant influences on human interactions (Booysen, 2005; Nkomo and Cox, 1996). Booysen (2005) explains the nature of the three dominant social identities in the workplace; Africans may now have political power and although the shifts have begun taking place in the workplace, this has not been as dramatic as expected and many Africans are frustrated by the continual waiting for transformation. White males by contrast feel threatened by a perceived lack of future opportunities and feelings of being unvalued, especially when they are expected to mentor and coach new African recruits. The third group find themselves in the middle, or somewhat in between white males and Africans. These are Indians, coloureds and white females who were not sufficiently white or of the wrong gender to benefit from apartheid and now find themselves not being black enough.

Thomas and Jain (2004) mention the growing schism between Blacks and coloureds and Indians. They discus the work of Valentine which talks of "hierarchies of oppression" 
where different disadvantaged groups compete with each other for resources. This has played itself out in a ruling in an anti-discrimination case in an arbitration court in April 2006 (Van Gass and Mde, 2006). The Arbitration Court ruled that state power utility Eskom had acted correctly in appointing an African engineer in place of a more qualified coloured engineer because the African engineer had been more disadvantaged than the coloured engineer by past discriminatory laws and practices. This study sets out to examine the effect of the employment equity legislation on the psychological contracts as experienced by these three social groupings.

\section{Impact on Psychological Contracts of Transition in South Africa}

Employees will over time, by means of evaluation, mentoring and the assignment of greater responsibility, develop higher levels of human capital. Although it is generally regarded that development is the responsibility of the individual, most organisations support the process to retain the best employees (Lepak \& Snell, 1999). In the context of employment equity programmes training is not only supported by the organisation but in the case of designated groups, this is the core of the programme and serves to support and reinforce the existence of the three dominant social identities.

As the level of individual human capital grows, the employee develops skills that are both firm specific and valuable to the broader labour market (Trevor, 2001). As transferability increases, the employee becomes more visible to the external labour market making it more possible to exit (Gardner, 2005). Many South African companies have experienced problems in retaining highly skilled black employees which further 
slows the rate of transformation within the organisation (Bennet, 2001; Booysen, 2005). The likelihood of turnover will increase as they develop more skills that are valuable to a broader labour market and/or they perceive serious violations to their relational psychological contracts. The nature of the psychological contract entered into with new black employees will by necessity be of a relational nature as the organisation engages on a long-term programme of developing the skills and talents of employees to retain them and deploy them to senior and key knowledge intensive roles in the organisation. In exchange for their loyalty and commitment, such employees will expect continued professional development and membership of the broader identity group (Rousseau \& McLean Parks, 1993, Thompson \& Bunderson, 2003). This is supported by Maharaj (2003), who states that white managers believe that employment equity practices has led to a breakdown of the relational components of the psychological contract between them and their employer.

The Employment Equity Report (2004) in South Africa in a survey of employers of 2.2 million employees found at top management level, white males had a labour turnover figure of 9.35\%, African males and females, 29.8\%, while other PDIs had a $14.1 \%$ labour turnover rate.

\section{Aims of the Research}

Our research aimed to determine if the three social identity groups differ in terms of their;

- Perceptions of their psychological contracts,

- Perceptions of how the legislation has affected them 
- Correlations between, their employers' obligations to them, the extent to which they have been affected by legislation, and levels of job satisfaction with aspects of the psychological contract.

- Outcomes of the psychological contract in terms of intention to leave and labour turnover

\section{Methodology}

A survey using a pre-tested quantitative questionnaire was conducted (Zikmund, 1997). One hundred and ten part time MBA students in Johannesburg South Africa were asked to administer the questionnaire to middle managers randomly selected from across all industries. The students were tasked with using quota sampling (Zikmund, 1997) in order to obtain the correct mix of respondents to meet the data analysis needs. As the students are employed in over eighty different companies it was felt that this methodology would ensure that respondents from a broad range of industries were included in the study. Data was obtained from over 500 employees in a wide range of industries, age groups and years of service in their current organisations.

The employment relationship was assessed using Rousseau's (2000) Psychological Contract Inventory (PCI), which has been used in a range of international studies (Maharaj, 2003; Dabos \& Rousseau, 2004; Hui, Lee \& Rousseau, 2004). Rousseau granted permission for use of the instrument. The instrument assesses the individual's perception of the employer's obligation and their obligations to the employee. The PCI assesses the degree of fulfilment, change or violation, with regard to these obligations. A 
five point rating scale is used. A scoring system is provided to measure the various components of the psychological contract e.g. transaction components. Rousseau reports a reliability level of 0.70 .

Intention to leave was measured using an existing three-item scale assessing the employee's intention to leave the organisation. The scale uses a five-point rating scale and has a coefficient alpha of 0.83 (Cook, Hepworth, Wall and Warr, 1981; Maharaj, 2003). The influence of employment equity practices was measured using an 8 item questionnaire developed and used by Maharaj (2003) in her study in one organisation in South Africa. The scale uses a five-point rating scale and Maharaj reported a 0.92 reliability coefficient. That questionnaire assessed the employee's beliefs on the influence of the Employment Equity Act as a whole on their relationship with the employer.

\section{Data Analysis}

The data was analysed using the NCSS system. Descriptive and inferential techniques were used. A correspondence analysis (Bendixen and Sandler, 1995) showed that the position "Not at all” point on the scale is considerably further from "Slightly" than would be acknowledged in the assumption that the scales are interval in nature. The Rousseau (2001) scoring system was used to establish the factor scores. ANOVA, Chi Square, and Pearson correlations were used to test at the 0.05 significance level (Zikmund,1997). Significant differences are indicated with an asterisk *. 
Limitations We may caution against assuming representivity as the sample was drawn from Johannesburg and Gauteng only. We also only sourced the employee's perceptions and not those of employers. We cannot claim causality, only co-existence of the factors as this was not a longitudinal study.

\section{Presentation of results}

Data from the 521 usable questionnaires revealed the following findings. Because of some missing data on the questionnaires, some totals below do not always equal 521.

The sample is detailed on a demographic basis below.

\section{Table 1: Sample Description}

\begin{tabular}{|l|c|c|c|c|c|}
\hline Sample & African & Coloured & Indian & White & Grand Total \\
\hline Male & 100 & 17 & 46 & 206 & 369 \\
Female & 46 & 21 & 34 & 46 & 147 \\
\hline Grand Total & 146 & 38 & 80 & 252 & 516 \\
\hline
\end{tabular}

\section{Demographic groupings}

For the purposes of this study the sample was divided into the three groups described by Booysen (2005)

- White Males, now the most discriminated against in terms of legislation

- African, Black males and females who are perceived to be the greatest beneficiaries of the various pieces of legislation

- Other Previously Disadvantaged Individuals (PDI), also known as the "middle group” as defined by Booysen (2005), which include white females, Indians and Coloureds but exclude Africans and white males. 
The breakdown of the sample into these three groups is shown below:

Table 2: The Demographic Composition of The Sample

\begin{tabular}{|c|c|c|}
\hline White Male & African & Other PDI* \\
\hline $40 \%$ & $28 \%$ & $32 \%$ \\
\hline
\end{tabular}

*as defined in the text

Table 3 gives the age break down of the sample

Table 3: Ages Of The Respondents

\begin{tabular}{|c|c|c|c|}
\hline Below 30 & $\mathbf{3 0}-\mathbf{3 9}$ & $\mathbf{4 0}-\mathbf{4 9}$ & $\mathbf{5 0}$ or more \\
\hline $4.6 \%$ & $55.1 \%$ & $28.7 \%$ & $11.8 \%$ \\
\hline
\end{tabular}

Table 4 indicates the range of years of service with their current employer

Table 4: Years With Current Company

\begin{tabular}{|c|c|c|}
\hline less than 5 & $\mathbf{5 - 8}$ & $\begin{array}{c}\text { 9 or more } \\
\text { years }\end{array}$ \\
\hline $48.8 \%$ & $27.7 \%$ & $23.5 \%$ \\
\hline
\end{tabular}

This shows the relatively high level of mobility of the sample a feature of the new world of work (Kinner and Sutherland, 2002). 


\section{Education}

Fifty three percent of the sample had a postgraduate qualification, twenty two percent a first degree, thirteen percent a post school diploma and twelve percent a matriculation (school completion) certificate.

\section{Results}

a) The perceptions of the three groups of the impact of Employment equity legislation

The questionnaire by Maharaj (2003) indicates to what extent the 3 groups feel they have been affected by the legislation. The scores are on a 5 point scale: 1 being "not at all”, 5 “to a great extent”.

Table 5: Effect of Employment Equity Legislation

\begin{tabular}{|l|c|c|c|c|}
\hline Question & $\begin{array}{c}\text { White } \\
\text { Males }\end{array}$ & $\begin{array}{c}\text { Other } \\
\text { PDI }\end{array}$ & African & Probability \\
\hline $\begin{array}{l}\text { To what extent has the EE Act } \\
\text { changed: }\end{array}$ & & & & \\
\hline Your obligation to your organisation & 0.16 & 1.29 & 1.85 & $0.000^{*}$ \\
\hline $\begin{array}{l}\text { Your organisation's obligation and } \\
\text { commitment to you }\end{array}$ & 0.69 & 1.48 & 1.88 & $0.000^{*}$ \\
\hline $\begin{array}{l}\text { How have the employment equity } \\
\text { practices in your organisation } \\
\text { positively influenced: }\end{array}$ & 0.90 & 1.59 & 1.78 & $0.000^{*}$ \\
\hline Your future earning potential & 0.20 & 1.47 & 1.86 & $0.000^{*}$ \\
\hline $\begin{array}{l}\text { Your current reward and } \\
\text { remuneration }\end{array}$ & 0.42 & 1.94 & 2.42 & $0.000^{*}$ \\
\hline $\begin{array}{l}\text { Your current training and } \\
\text { development opportunities }\end{array}$ & 0.37 & 1.59 & 1.61 & $0.000^{*}$ \\
\hline $\begin{array}{l}\text { Recognition and reward for your } \\
\text { performance }\end{array}$ & 0.74 & 1.73 & 2.09 & $0.000^{*}$ \\
\hline $\begin{array}{l}\text { Your assignment to challenging } \\
\text { work in line with your skill and } \\
\text { ability }\end{array}$ & 1.39 & 1.52 & 1.96 & 0.073 \\
\hline Your job satisfaction & 0.31 & 1.51 & 1.44 & $0.000^{*}$ \\
\hline Your working relationship to & & & \\
\hline
\end{tabular}




\begin{tabular}{|l|l|l|l|l|}
\hline colleagues & & & & \\
\hline The company culture & 0.73 & 0.86 & 1.02 & 0.676 \\
\hline The honesty of senior management & 0.13 & 0.36 & 0.75 & 0.125 \\
\hline
\end{tabular}

The table indicates for the first eight items that there were significant differences between the three groups. The first two items show how the psychological contract has differentially been affected by the legislation with the African group perceiving the greatest change in the psychological contract. The remaining six items showing significant differences, all relate to individually based performance management issues. Inspection of the table shows that in all but one of the cases, job satisfaction, every case the direction of the differences is exactly aligned to the level in which the three groups are differentially affected by the acts, with Africans consistently perceiving that they have been the most positively affected by the legislation. Interestingly the last three items showed no significant differences. These items all relate to general company issues, i.e. external to the individual employee.

\section{b) Labour Turnover and the Three Groups}

A cross tabulation of the three demographic groups by years in company was drawn up. A Chi Square (Zikmund,1997) test of dependency on the resulting data revealed a chisquare statistic of 25.2 at 4 degrees of freedom, which had a probability level of 0.000004, indicating that there is a significant relationship between demographic group and length of tenure. An inspection of the contingency table revealed that Africans are overrepresented in the less than 5 year category and underrepresented in the over 10 year grouping, White males in the over 10 year category, with other PDI (the “middle group”) contributing very little to the chi square contribution. This finding illustrates that one of 
the outcomes of a disruption in the psychological contract, labour turnover, is significantly related to demographic grouping as per the labour regulations. This is possibly a reflection of the intention of the legislation to create a far more favourable labour market for African employees, whilst White males stay in their jobs longer because of an artificially created, limited labour market.

\section{c) Intention to leave and the three Groups}

The three item scale on intention to leave, yielded the following results.

\section{Table 6: Intention To Leave}

\begin{tabular}{|l|c|c|c|c|}
\hline Question & $\begin{array}{c}\text { White } \\
\text { Males }\end{array}$ & Other PDI & African & Probability \\
\hline $\begin{array}{l}\text { How likely is it that you will } \\
\text { actively look for a new job in the } \\
\text { next year }\end{array}$ & 2.76 & 2.88 & 3.12 & 0.108 \\
\hline You often think about leaving & 2.72 & 2.64 & 2.86 & 0.376 \\
\hline $\begin{array}{l}\text { You will probably look for a new } \\
\text { job in the next year }\end{array}$ & 2.54 & 2.66 & 2.98 & $0.035^{*}$ \\
\hline
\end{tabular}

In each case the African respondents show the highest propensity to leave, with there being a significant difference on the ANOVA showing a high probability that Africans will be looking for a new job in the next year.

\section{d) Perceptions of the Employer's obligations}

Table 7 shows the factor scores for the three demographic groups on each of Rousseau's (2000) psychological contract factors regarding the employer obligations, under her 
major headings, which are indicated in bold. The probability level in all of the following tables is the output of the ANOVA for between group differences on the factor scores. Significant differences are indicated with an asterisk.

Table 7: Perceptions about Employer

\begin{tabular}{|l|c|c|c|c|}
\hline Factor & $\begin{array}{l}\text { White } \\
\text { Males }\end{array}$ & Other PDI & African & Probability \\
\hline Balanced & & & & \\
\hline $\begin{array}{l}\text { Career development external } \\
\text { market }\end{array}$ & 2.83 & 2.72 & 2.75 & 0.569 \\
\hline $\begin{array}{l}\text { Dynamic performance } \\
\text { requirements }\end{array}$ & 3.41 & 3.42 & 3.28 & 0.400 \\
\hline $\begin{array}{l}\text { Career development Internal } \\
\text { market }\end{array}$ & 3.04 & 3.08 & 3.09 & 0.909 \\
\hline Relational & & & & \\
\hline Loyalty & 2.96 & 3.10 & 2.96 & 0.347 \\
\hline Security & 3.37 & 3.25 & 3.25 & 0.392 \\
\hline Transactional & 2.31 & 2.21 & 2.23 & 0.345 \\
\hline Short term & 2.48 & 2.49 & 2.57 & 0.517 \\
\hline Narrow & & & & \\
\hline Transitional & 2.49 & 2.58 & 2.34 & 0.159 \\
\hline No trust & 2.47 & 2.57 & 2.50 & 0.706 \\
\hline Uncertainty & 2.19 & 2.02 & 2.14 & 0.257 \\
\hline Erosion & & &
\end{tabular}

The table shows that there are no significant differences between the three groups in terms of their perceptions about the employers' obligations towards them. When looking at the four components of Rousseau's (2000) psychological contract for employers, the overall weightings are from highest to lowest; balanced (3.26) relational (3.15) transactional (2.4) and transitional (2.37) component scores, indicating a healthy set of expectations of mutual benefit to one another, with very little evidence of a disruption in the previous psychological contract 9 i.e. the transitional elements), Hence the previous tables show that although there is a perception that the external environment of business 
has changed this has not been translated into a change in the internal reciprocity between employer and employee. Other features in the date are the very high scores around dynamic performances requirements and the very low scores around erosion of the relationship.

e) Perceptions of obligations to the Employer

Table 8 illustrates the findings of the respondents' obligations toward their organisations.

Table 8: Perceptions about Employee’s Obligations

\begin{tabular}{|l|c|c|c|c|}
\hline Factor & $\begin{array}{l}\text { White } \\
\text { Males }\end{array}$ & Other PDI & African & Probability \\
\hline Balanced & 3.28 & 3.42 & 3.66 & $0.001^{*}$ \\
\hline $\begin{array}{l}\text { Career development external } \\
\text { market }\end{array}$ & 4.24 & 4.31 & 4.18 & 0.249 \\
\hline $\begin{array}{l}\text { Dynamic performance } \\
\text { requirements }\end{array}$ & 1.67 & 1.58 & 1.76 & 0.120 \\
\hline $\begin{array}{l}\text { Career development internal } \\
\text { market }\end{array}$ & & & & \\
\hline Relational & 4.00 & 3.80 & 3.63 & $0.000^{*}$ \\
\hline Loyalty & 3.05 & 2.74 & 2.53 & $0.000^{*}$ \\
\hline Security & & & & 0.120 \\
\hline Transactional & 1.67 & 1.58 & 1.76 & 0.222 \\
\hline Short term & 2.48 & 2.41 & 2.61 & \\
\hline Narrow & & & & \\
\hline
\end{tabular}

The table shows three areas of significant difference. Firstly, around building up one's career capital (Trevor, 2001) in the external labour market. With the African group indicating they are the most involved in building up their marketability with the external labour market, also referred to as career capital. The White males showed the lowest propensity to do this. Secondly, both items under the relational factor showed significant differences, with White males indicating the highest and the Africans the lowest 
indicators of loyalty and job security (i.e. intention to stay) in their current jobs. Again these differences are in the expected direction and correlate with their involvement in the external career development finding.

Interestingly there are no significant differences in the areas of the transactional nature of the relationship, the performance requirements and career development opportunities internal to the company. When looking at the three components of Rousseau's (2000) psychological contract for employees the ordering from highest to lowest for the whole sample is balanced (3.89) relational (3.3) and transactional (2.05) again showing a mutually beneficial set of expectations.

It is of interest that there is a similarity of perceptions from both the employer and employee perspectives that balanced and relational contracts are implied in the workplace.

\section{f) Perceptions of Job Satisfaction}

The final part of the Rousseau questionnaire revealed the following data with 1 meaning not at all and 5 a great deal. 
Table 9: Overall satisfaction and commitment levels

\begin{tabular}{|l|c|c|c|c|}
\hline Question & $\begin{array}{c}\text { White } \\
\text { Males }\end{array}$ & Other PDI & African & Probability \\
\hline $\begin{array}{l}\text { Overall how well does your } \\
\text { employer fulfil its commitments to } \\
\text { you }\end{array}$ & 3.69 & 3.52 & 3.41 & $0.028^{*}$ \\
\hline $\begin{array}{l}\text { In general how well does your } \\
\text { employer live up to its promises }\end{array}$ & 3.55 & 3.33 & 3.28 & $0.039 *$ \\
\hline $\begin{array}{l}\text { Overall how well have you } \\
\text { fulfilled your commitment to your } \\
\text { employer }\end{array}$ & 4.27 & 4.27 & 4.15 & 0.254 \\
\hline $\begin{array}{l}\text { In general how well do you live } \\
\text { up to your promises to your } \\
\text { employer }\end{array}$ & 4.19 & 4.21 & 4.12 & 0.527 \\
\hline $\begin{array}{l}\text { Overall how satisfied are you in } \\
\text { your job }\end{array}$ & 3.62 & 3.61 & 3.38 & 0.101 \\
\hline
\end{tabular}

In each case the African respondents show the least sense of engagement with their current employer. The two significant differences deal with perceptions around the employers living up to its commitments and are again ordered in line with the level to which the three groups are differentially affected by the legislation and with the Africans showing least satisfaction with the way in which the employing company is meeting its obligations.

What is notable in the table is the high levels of all the scores indicating the respondents are satisfied with the employers' fulfilment of their obligations them, with the way they are fulfilling their side of the contract and are satisfied with their jobs, and yet many of them intend to leave as shown in Table 6.

\section{g) Perceptions and Attitudes towards Employment Security}

Pearson correlations were calculated between Rousseau Factor on employee security i.e. how long the respondents intend to stay with the organization, (with intention to leave 
being seen as the ultimate break in the psychological contract) and each of the 10 factors relating to perceptions about the employer contribution to the psychological contract for the total sample, for the three demographic groups. In every case there was a significant relationship between these factors indicating dependence between their perceptions of the employers' obligations towards them and their intention to stay. The direction of the relationships was positive for all the transactional factors, and negative for all the balanced and relational factors, which supports the meaning of the factors.

Correlations were also performed on the security factor and all of the items relating to the effect of the Employment Equity Act in Table 9 above. Significant negative relationships were found in every case i.e. respondents were more likely to intend to stay with the organisation the less they felt they were positively affected by the legislation. Stated in another way those who felt they had benefited the most by the legislation were the most likely to intend to leave. The highest correlation for the whole sample was with job satisfaction followed by the two items on reward, remuneration and recognition. Examining the three demographic groups separately; job satisfaction was in the highest two correlations, the other highest correlates were as follows; for the white males reward and remuneration, for the African group future earning potential, for the other PDIs (the middle group) the assignment of challenging work.

\section{Conclusions}

The labour legislation has changed the power distance between the three social groups/identities but has reinforced these identities, as reflected in differences in the 
psychological contract. The research showed significant differences amongst the three social identity groupings in their perceptions of employment equity legislation, labour turnover, intentions to leave, perceptions of their obligations to the employer, sense of satisfaction and employment security.

As could be expected African managers felt most positive about the employment equity legislation and it was expected that the legislation would positively affect their future prospects, rewards and earnings and opportunity to use their skills and abilities. This is one of the primary objectives of the legislation and demonstrates the effectiveness of the legislation. However, the survey also showed a higher turnover of African managers and their intention to leave, this is indicative of the strong influence that a favourable labour market has despite employers attempting to build a relational or balanced psychological contract. The other groups, white males and the "middle group" had similar perceptions of the employer but differed from the African group in that they were not as strongly focussed on developing their own marketability, or transferability within the broader labour market (Gardner, 2001). As expected the highest degree of loyalty can be expected from white males, as they perceive their mobility the lowest.

Despite the differences in psychological contract, there were no significant differences between the three groups on their views of the employer or of employer obligations towards the respective respondents. The most significant differentiator between the groups is the labour legislation and historical social identities and accounts for the differences in psychological contract. This finding shows that external labour market 
forces play an important role in psychological contract formation which in turn influences many human resources practices. This has significant implications for the understanding and management of international businesses. Multinational firms operating in such environments need to be familiar with the legislative environment and other country specific factors in order to operate effectively. They should benchmark against best practice in local firms.

A further implication of the research is that the assumed linkage between job satisfaction (or dissatisfaction) and labour market turn-over (e.g. Flood et al, 2001; Rousseau, 2004) is weakened by labour market conditions. In our population there were no significant differences between the groupings in terms of job satisfaction, yet African respondents showed a significantly higher propensity to find a new job in the short-term. This is consistent with the views of the Corporate Leadership Council (1999), who reflect that the link between employee satisfaction and intention to leave is weakening as increasingly highly satisfied employees leave their organisations for new opportunities. The Council contends that this de-linking is driven by the increased visibility of employment offers by other organisations and the reduction of switching costs from one organisation to another. This finding was not as strong in the case of white males and the middle group as it was for Africans and warrants significant further research.

The impact of social groups that are differentiated by labour market regulations on HR management practices are potentially wide-ranging and the long-term effects are uncertain. The differences in psychological contract by social group require 
differentiated HR management strategies to, for instance, manage talent and raises serious questions about the effectiveness of traditional diversity management programmes. An additional area of concern for South African employers is the perception amongst all groups that much is expected of them in terms of performance but little is offered in terms of internal development opportunities and could be indicative of a sense of frustration created by the legislation. This is understandable for white males as they are the group that has traditionally benefited the most in the South African workplace, but is more surprising for PDIs, both Africans and the middle group. PDIs are the target of transformation efforts and it is expected that most training and development focus is on them, however, African managers are the least engaged with their employers and feel that firms are not meeting their obligations towards them. This is less strongly felt by the middle group and warrants further investigation.

In conclusion, while the employment equity legislation is successful in promoting the prospects of African managers, and to a lesser extent, those of the middle group, it has the unfortunate consequence of reinforcing the existence of the three social identities in the South African workplace. This necessitates the development of HR strategies that differentiate between the groupings while attempting to build a united organisational culture, a nigh-impossible task when the differential pull-factors created by the labour market are so strong.

The legislation has played a positive role in kick-starting the transformation of South African workplaces by altering the power distance between the social groups but will 
require a degree of refinement to overcome the negative consequence of the three social identities over the long-term but may be necessary to build a truly non-racial and nondiscriminatory society.

\section{References}

Armstrong, M. \& Murlis, H. (1998). Reward management. London: Biddles Ltd.

Bendixen, M. and Sandler, M. (1995). Converting verbal scales to interval scales using correspondence analysis. Management Dynamics 4(1): 32-50.

Bennet, J. (2001). March 25. Companies bleeding skilled blacks at a rapid rate. Sunday Times.

Booysen, L. (2004a). Evaluation of Org X Employment Equity implementation and retention strategies. June, 2004. Johannesburg: Org X.

Booysen, L. (2004b). Org Y: Leadership across difference report. December. Centre for Creative Leadership in collaboration with the Graduate School for Business Leadership, UNISA: Midrand.

Booysen, L. (2005). Social Identity Changes in South Africa: Challenges facing leadership. Inaugural lecture at Graduate School of Business leadership, University of South Africa. Midrand. 23 June 2005.

Bouche, J. \& and Booysen, L. (2005). Facing the unknown: introducing BEE into SMME’s. Management Today, 21(4):46-47.

Bussin, M. (2002). Retention strategies: remuneration answers. Johannesburg: Knowledge Resources.

Cappelli, P. (1997). Rethinking the nature of work: a look at the research evidence. Compensation and Benefits Review, July/August: 50-59. 
Cook, J.D., Hepworth, S.J., Wall, T.D. and Warr, P.B. (1981). The Experience of Work. New York, Academic Press.

Dabos, G.E. \& Rosseau, D.M. (2004). Mutuality and Recprocity in the Psychological Contracts of Employees and Employers. Journal of Applied Psychology. Vol. 89. No 1: 52-72.

Esterhuyse, W.P. (2003). The challenge of transformation: breaking the barriers. South African Journal of Business Management, 34(3): 1 - 8.

Flood, P.C., Turner, T., Ramamoorthy, N. \& Pearson, J. (2001). Causes and consequences of psychological contracts among knowledge workers in the high technology and financial services industries. International Journal of Human Resource Management, 12(7):1152-1165.

Gardner, T.M. (2005). Interfirm Competition for Human Resources: Evidence from the Software Industry. Academy of Management Journal, 48(2):237-256.

Government of South Africa. Employment equity report (2004).

Hui, C, Lee, C. \& Rousseau, D.M. (2004). Psychological Contracts and Organizational Citizenship behaviour in China: Investigating Generalizability and Instrumentality. Journal of Applied Psychology. Vol. 89. No 2:311-321.

Lepak, D.P. \& Snell, S.A. (1999). The Human Resource Architecture: Toward a Theory of Human Capital Allocation and Development. Academy of Management Review, 24(1): 31-48.

Maharaj, K. (2003). A comparative study of the psychological contract of white and black managers. Unpublished Master of Management research report. University of the Witwatersrand. South Africa. 
Millward, L.J. \& Brewerton, P.M. (2001). Psychological contracts: employee relations for the twenty-first century? In: Robertson, I.T. \& Cooper, C.L. (Eds.), Personnel Psychology and Human Resource Management. London: Wiley.

Ngambi, H. (2002). The role of Emotional Intelligence in transforming South African organisations. Proceedings of the International and Management Sciences Conference. Vanderbijlpark, South Africa.

Nkomo, S.M. and Cox, T.J. (1996). Diverse Identities in Organizations. In: S. Clegg, W.R. Nord, \& C. Hardy (Eds.) Handbook of Organization Studies. London: Sage. Reddy, R. (2004). Factors affecting the Mobility and Retention of Black Knowledge Workers. Unpublished MBA research report. University of the Witwatersrand. South Africa.

Restubog, S.L.D., Bordia, P. and Tang, R.L. (2006). Effects of psychological contract breach on performance of IT employees: The mediating role of affective commitment. Journal of Occupational and Organizational Psychology. 79: 299306.

Robinson, S.L. and Morrison, E.W. (2000). The development of psychological contract breach and violation: a longitudinal study. Journal of Organizational Behavior. 21:525-546.

Rousseau, D.M. (2000). Psychological Contract Inventory. Technical report NO 2000 02. Heinz School of Public Policy and Management, Carnegie Mellon University. Rousseau, D.M. (2004). Psychological Contracts in the Workplace: Understanding the Ties That Motivate. Academy of Management Executive, 18(1):120-127.

Rousseau, D.M. \& McLean Parks, J. (1993). The contracts of individuals and 
organisations. Research in Organizational Behavior, 15:1-47.

Selby,K.. (2005). Space Creation - an alternative strategy for achieving employment equity at senior management level. Unpublished Masters of Business Administration research report. Gordon Institute of Business Science, University of Pretoria. South Africa.

Thomas, A. and Jain, H.C. (2004). Employment equity in Canada and South Africa: progress and propositions. International Journal of Human Resources Management, 15(1):36-55.

Thompson, J.A. \& Bunderson, JS. (2003). Violations of Principle: Ideological Currency in the Psychological Contract. Academy of Management Review, 28(4):571-586.

Trevor, CO. (2001). Interactions among actual ease-of-movement determinants and job satisfaction in the prediction of voluntary turnover. Academy of Management Journal 44:621-638.

Van Gass, C. and Mde, V. (2006). April 15. Arbitration Court rules in favour of Eskom employing a black engineer over a coloured one. Business Day.

Winterton, A. (2004). A conceptual model of labour turnover and retention. Human Resources Development International. 7(3) 371 -390.

Zikmund, W.G. (1997). Business Research Methods. Dryden. Fort Worth. 